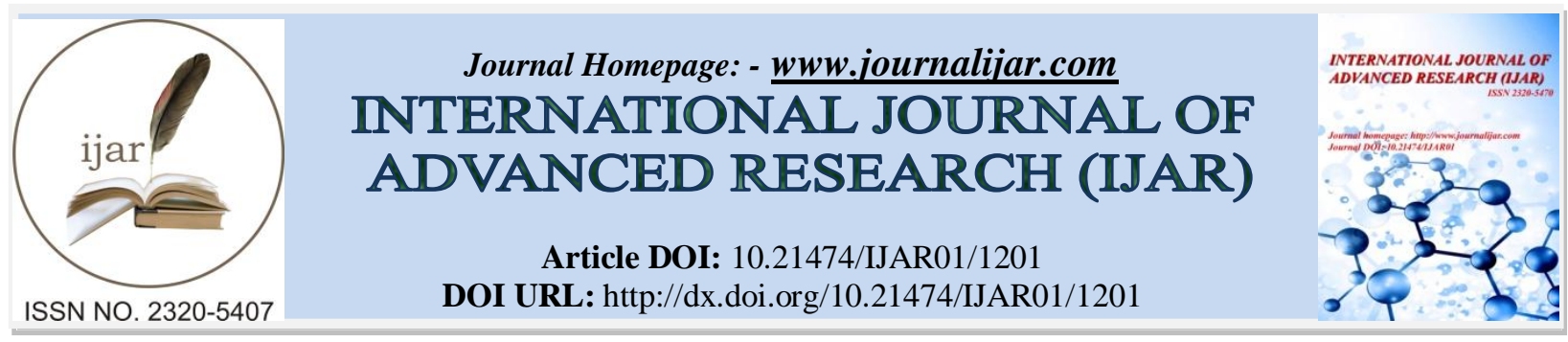

RESEARCH ARTICLE

\title{
EFFECT OF DI DIESEL ENGINE PERFORMANCE WITH METHANOL AS AN ADDITIVE IN DIESEL - BIODIESEL (PPME) BLENDS.
}

Venkateswara Rao P. and Ramesh S.

Dept. of Mechanical Engineering, Kakatiya Institute of Technology \& Science Warangal-506015, Telangana, INDIA.

\section{Manuscript Info}

Manuscript History

Received: 12 June 2016

Final Accepted: 13 July 2016

Published: August 2016

Key words:-

Diesel Engine, Methanol,

Additive, Performance,

Biodiesel, Emissions.

\section{Abstract}

Oxides of nitrogen and particulate matter are the main pollutants in the tailpipe emissions of engines operating with biodiesel as fuel. Experiments were conducted to evaluate the effects of using methanol as an additive with a diesel - biodiesel mixture (DBD100 is 50\% diesel and 50\% biodiesel in volume) on the engine performance. Methanol added as an additive to diesel-biodiesel mixture by volume percent of 5\%,10\% and 15\% (DBD85M15). The results of dieselbiodiesel mixture with methanol as an additive in blends compared with diesel. The results could reduce the exhaust gas temperature due to the higher oxygen content and increase heat of evaporation of the blended fuel, hence reduces the $\mathrm{HC}, \mathrm{NO}_{\mathrm{x}}$ emission and soot compared to diesel fuel.

Copy Right, IJAR, 2016,. All rights reserved.

\section{Introduction:-}

The resources of petroleum fuel are depleting day by day and huge increase in demand of fuels, as well as stringent regulations of environment pollution directs the researchers to search for new suitable alternative fuels for diesel engines. It is suggested that oxygenated fuel helps to reduce greenhouse gas emissions and promotes sustainable rural development by improving income, even still some resistance exist for usage. Additive is a chemical material added to base fuel to improve desirable chemical properties and also functions as a detergent or dispersed. Diesel fuel additives solve problems occur prior to burning and promote complete combustion of fuel in the combustion chamber which reduces engine deposits, smoke and emissions.

The results with DMC additive in concentrations of 5\%,10\% and 15\% shows an appreciable reduction of emissions such as particulate matter, oxides of nitrogen, smoke density and marginal increase in the performance when compared with diesel fuel [1]. The observation with DMM additive was CO, smoke emission, total number and mass concentration of particulate reduce significantly, while $\mathrm{HC}$ emissions and particulate matter increase slightly. [2-3].The result with dimethyl ether produce very low emissions, but the disadvantages are reduced viscosity, lubricity and vapour lock for its low boiling temperature [4]. Addition of the 15\% MEA in diesel gives 50-60\% reduction in smoke with shorter combustion duration and increased thermal efficiency. $\mathrm{CO}$ and $\mathrm{HC}$ emissions also decrease with the increase of MEA in the blend [5].

The oxygenated or metal based additives in the biodiesel - diesel blend produce reduced exhaust emissions as compared with diesel fuel [6]. The effect of DMM additive on particulate matter emission causes a substantial 
reduction, but $\mathrm{NO}_{\mathrm{x}}$ emission does not change [7]. Diethyl ether has been identified as a potential renewable biobased fuel and oxygenated additive. Tests on diesel engine with neat Karanja oil methyl ester as a base fuel and blends of 5, 10, 15 and 20\% of DEE by volume basis improve fuel properties like combustion characteristics, viscosity and cold starting problems [8]. The 10\% triacetin additive has better performance with COME in terms of combustion pressure and heat release rate. Mixing triacetin additive with biodiesel improves the cold flow, combustion efficiency, viscosity and reduces the engine detonation [9]. The results with oxygenated additives indicate that smoke and particulate emissions are reduced without sacrificing other emission characteristics and thermal efficiency due to the high oxygen content in the fuels [11]. When methanol used as a fuel additive, can provide higher oxygen content in the blend fuel and increase the heat of evaporation of blend fuel, which is an advantageous for reducing both $\mathrm{NO}_{\mathrm{x}}$ and soot. Moreover, alcohols could help to improve the poor low temperature and flow characteristics of biodiesel [12]. The present study aims to prepare biodiesel [10] and investigate the performance and emissions of a single cylinder diesel engine operating on biodiesel-diesel mixture with the additive of methanol blends, and to compare these results with those of diesel.

\section{Materiall and methods:-}

Transesterification process is used to make biodiesel from pongamia oil. Filtered oil is heated at $105^{\circ} \mathrm{C}$ temperature to remove all the water content as shown in figure 1 . Methanol of $99 \%$ pure, $120 \mathrm{ml}$ per liter of oil is added and stirred for ten minutes. Two milliliter of $98 \%$ pure sulfuric acid is added for each liter of oil, heated and stirred for one hour at $60^{\circ} \mathrm{C}$ in a closed conical beaker in acid treatment. The mixture is allowed to settle for four hours and glycerin is removed from methyl/ethyl ester shows figure 2 (a).

Methanol of $200 \mathrm{ml}$ ( $20 \%$ by volume) with 6.5 grams of $97 \%$ pure $\mathrm{NaOH}$ (Sodium Hydroxide) is thoroughly mixed until it forms a clear solution called "Sodium Methoxide". This solution is added to oil at $60^{\circ} \mathrm{C}$ temperature by stirring at 500 to $600 \mathrm{rpm}$ in a closed container. The solution turns into brown silky in colour at the end of reaction as shown in figure 3. After settlement of the mixture, glycerin is separated from biodiesel in the base treatment as in figure 2(b). The formed methyl ester is bubble washed with distilled water for about 30 minutes to remove soaps and un-reacted alcohol. Washing is repeated till the methyl ester separated with clear water as shown in figures $4-8$. Collected methyl ester is heated to remove water and used for experimental work.

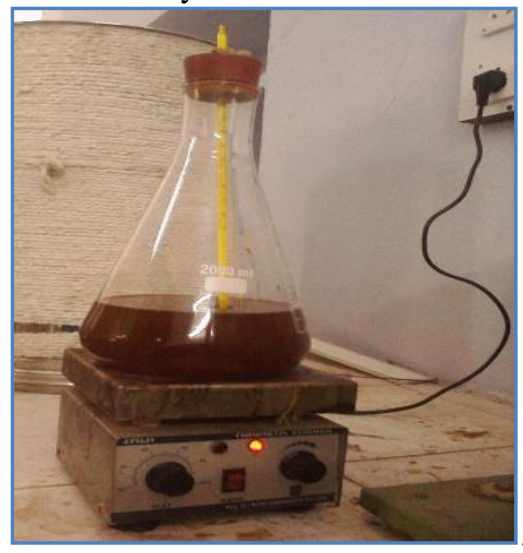

Fig. 1:- Initial heating of oil

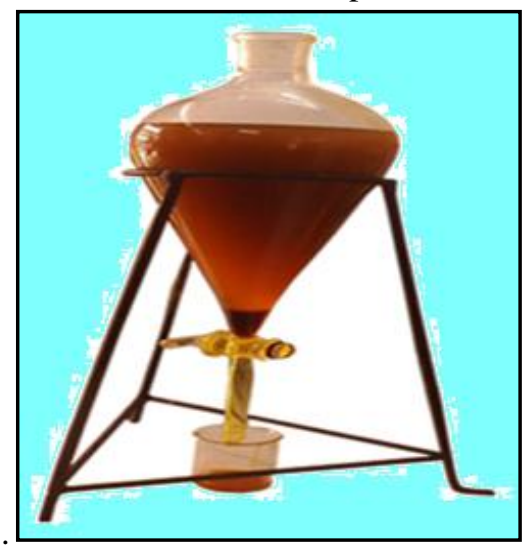

Fig. 2:- (a) and (b) Glycerin separation after acid and base treatment

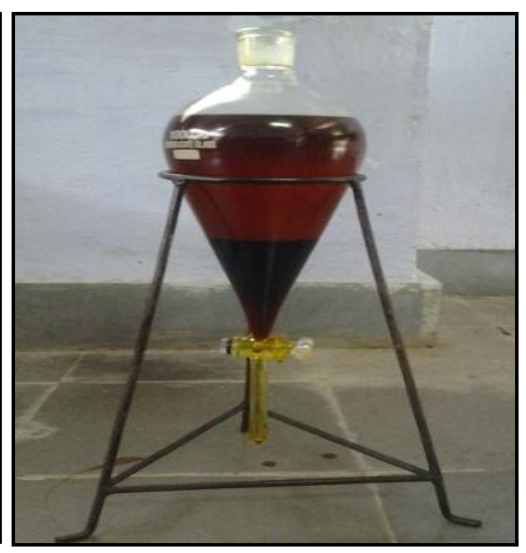

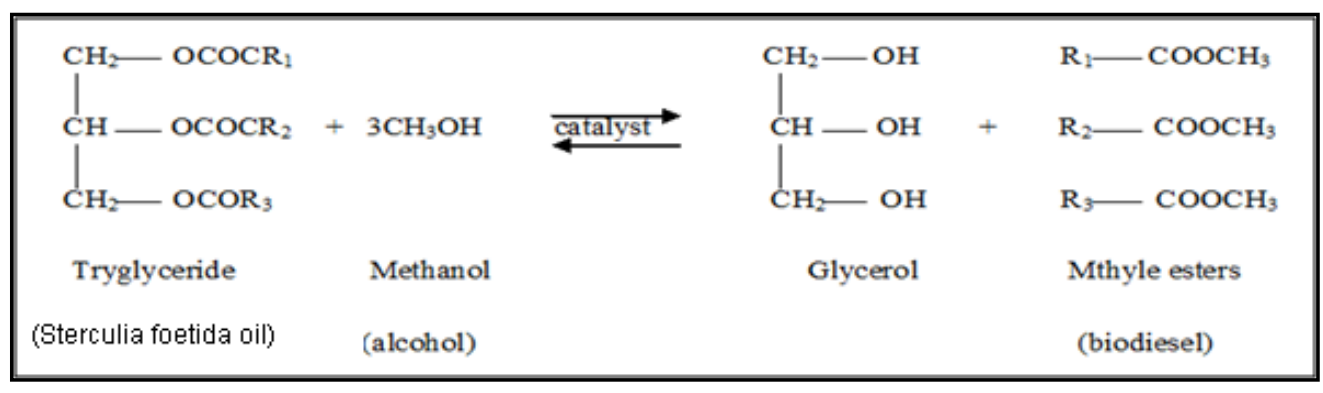

Fig. 3:- Reaction of Biodiesel formation. 


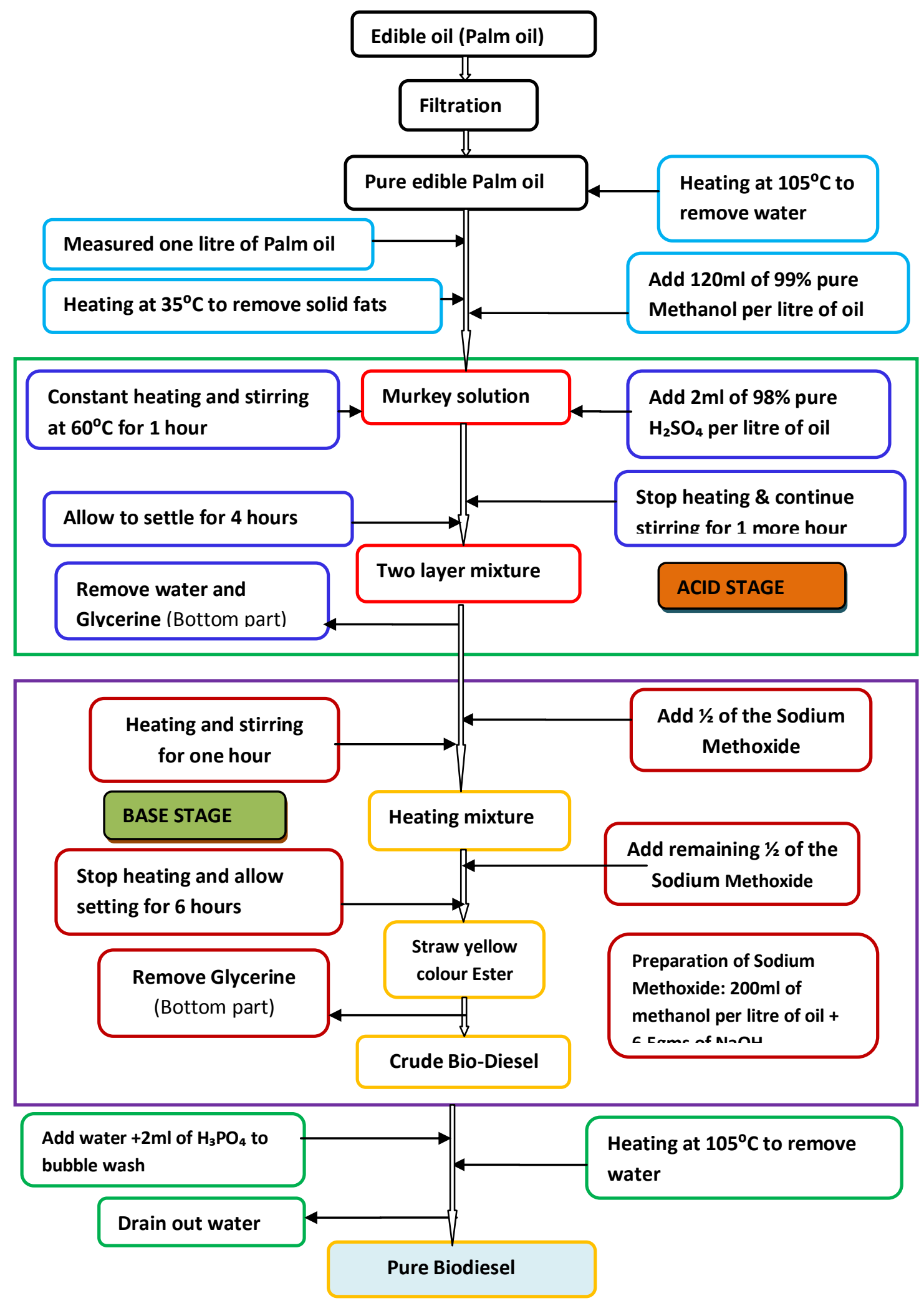

Fig. 4:- Flow Chart of Biodiesel production process. 


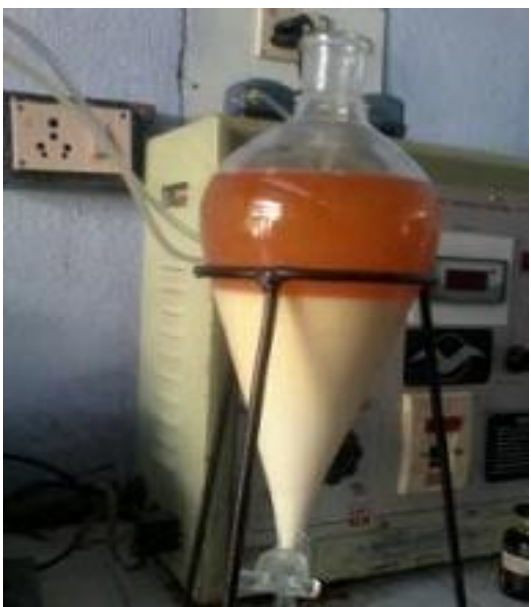

Fig. 5:- Soap water during water washing

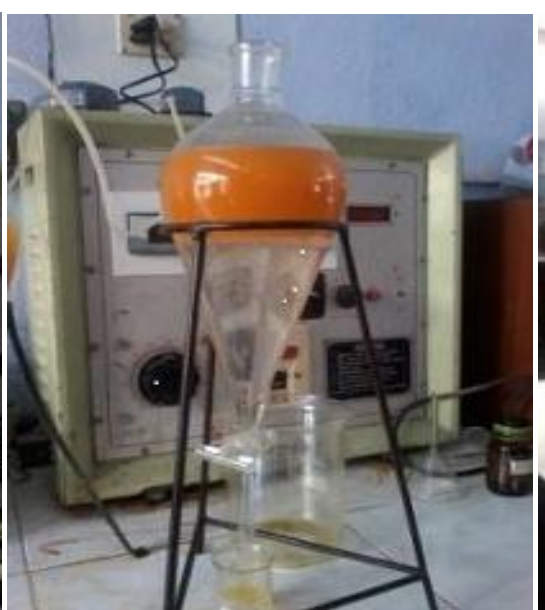

Fig. 6:- Clean water during water washing

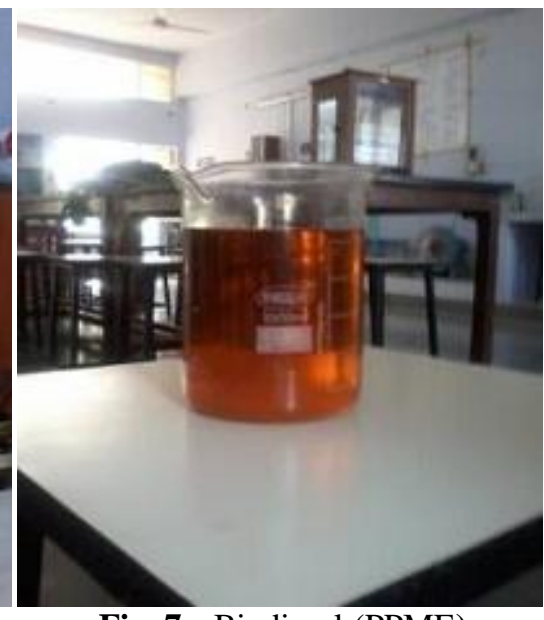

Fig. 7:- Biodiesel (PPME)

\section{Experimentation:-}

Experiments were conducted on a $\mathrm{C}$ I engine with diesel and D50BD50 - Methanol $\left[\mathbf{C H}_{3} \mathbf{O H}\right]$ at different percentages for a full load range of the engine. The blend fuels are prepared with methanol as an additive to the mixture (50\%diesel and 50\%biodiesel). The blend, proportions are 95\% diesel and biodiesel mixture with 5\% Methanol (DBD95\%M5\%), DBD90\%M10\% and DBD85\%M15\% as shown in Table 2. A water cooled eddy current dynamometer is coupled to the engine for precise loading and load applied on the engine is measured. During the test performance, exhaust emission parameters were measured. Exhaust temperatures and Fuel consumption were also measured to calculate the performance of the engine. Exhaust gas analyzer is used to measure $\mathrm{CO}_{2}, \mathrm{CO}, \mathrm{HC}, \mathrm{NO}_{\mathrm{x}}$ in exhaust gases and compared the results with diesel run. The experimental setup details are shown in Table 1.

Table 1 Engine details

\begin{tabular}{||l|l|}
\hline Engine & $\begin{array}{l}\text { Vertical, 4stroke, water } \\
\text { cooled with eddy current } \\
\text { dynamometer }\end{array}$ \\
\hline Rated power & $3.68 \mathrm{kw}(0) 1500 \mathrm{rpm}$ \\
\hline Cylinder bore & $80 \mathrm{~mm}$ \\
\hline Stroke length & $100 \mathrm{~mm}$ \\
\hline C R & $16: 1$ \\
\hline
\end{tabular}

Table 2. Percentage of fuel blends

\begin{tabular}{||c|c|c||}
\hline No & \multicolumn{1}{|c||}{ Fuel } & \multicolumn{1}{|c||}{ Fuel Blends } \\
\hline 1 & D100 & $100 \%$ Diesel (D) \\
\hline 2 & DBD95M5 & $95 \%$ DBD, 5\%Methanol \\
\hline 3 & DBD90M10 & $90 \%$ DBD, 10\%Methanol \\
\hline 4 & DBD85M15 & $85 \%$ DBD, 15\%Methanol \\
\hline
\end{tabular}

\section{Result and discussion:-}

The performance and emission parameters were measured for diesel, diesel-biodiesel mixture with Methanol additive blends and the results are as follows.

\section{Performance Analysis:-}

\section{Brake Thermal Efficiency (BTE):-}

From the figure 8 as the percentage of methanol increases, the trend in BTE is also increased and observed that reaches to diesel fuel efficiency. This may be due to efficient combustion of blend fuel as methanol contains more oxygen and releases higher amount of heat with less calorific value biodiesel-diesel mixture. The M15 has improved efficiency than M5 and M10 in the mixture, but less than diesel fuel by $2.1 \%$ at full load. The exhaust gas temperature is low in the case of methanol blends operation, lesser heat loss through the exhaust gases happen (Fig. 9). Hence improved brake thermal efficiency. 


\section{Brake Specific Fuel Consumption (BSFC):-}

The figure 10 shows the effect of methanol on BSFC. It can be seen that BSFC of M5, M10 and M15 increased slightly due to higher fuel consumption at all loads than diesel. This is because of the lower calorific value of biodiesel in the blend which contributes high consumption of fuel.

\section{Emissions Analysis:- \\ CO Emission:-}

The figure 11 shows the variation of $\mathrm{CO}$ in difference percentage of methanol blends. This is due to incomplete combustion of fuel. The $\mathrm{CO}$ emission is low initially and increases with increase in load. This increase at higher loads is due to increase in speed and hence the time provided for combustion decrease and the increased ignition delay period, resulting in complete combustion hence increase in $\mathrm{CO}$ emission. However the $\mathrm{CO}$ emission from mixture fuel with methanol is far less than neat diesel fuel.

\section{HC emission:-}

The HC emission is formed when fuel remains unburned due to flame front collision that results in knocking. The observation on $\mathrm{HC}$ emission from figure 12 is that at any load the fuel mixture with methanol is far less than neat diesel. As the methanol percentage increases and the load on engine increases $\mathrm{HC}$ emission decreases for percentages of testing blend fuels and M15 blend fuel have 25.6\% less than diesel at full load.

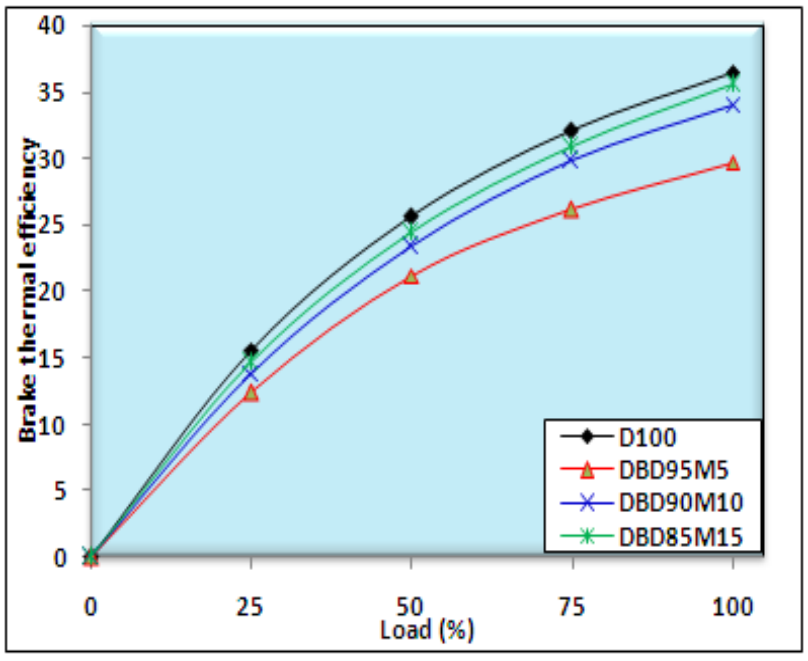

Fig. 8:- $B T E$ variation with load

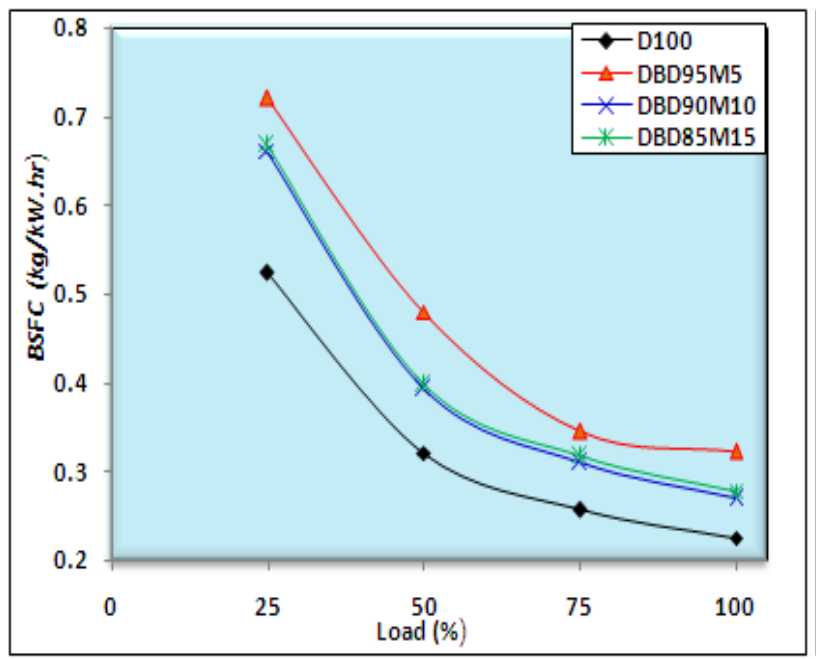

Fig. 10:- $B S F C$ variation with load

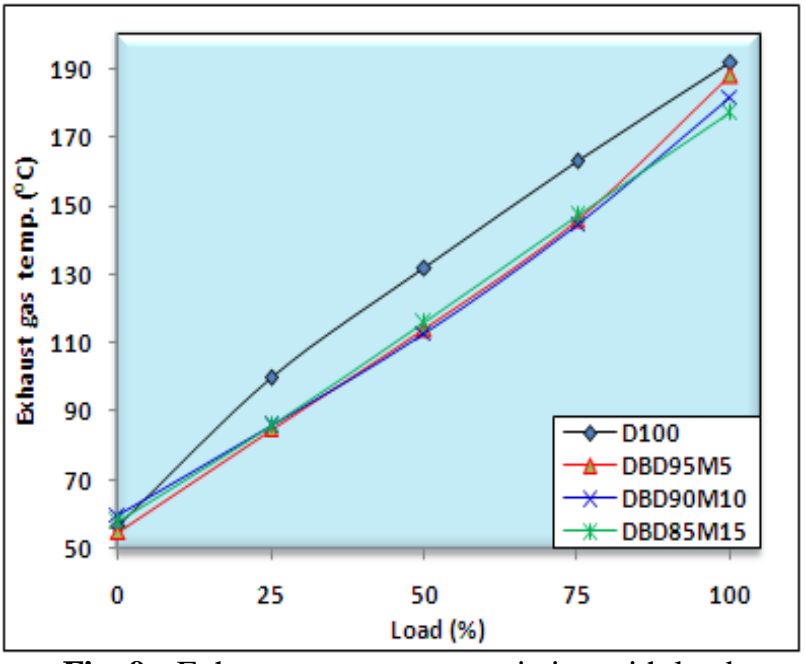

Fig. 9:- Exhaust temperature variation with load

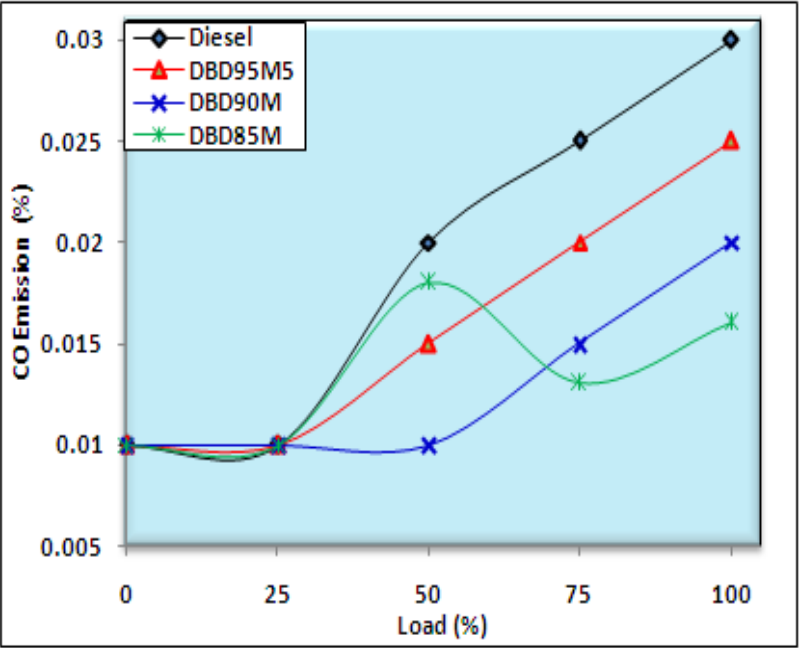

Fig. 11:- $\mathrm{CO}$ emission variation with load 


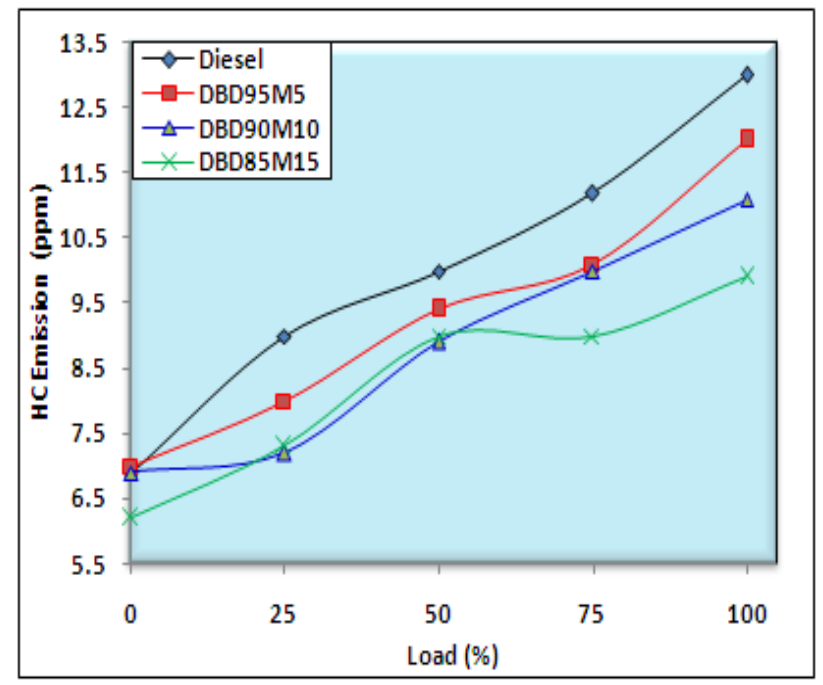

Fig. 12:- HC emission variation with load

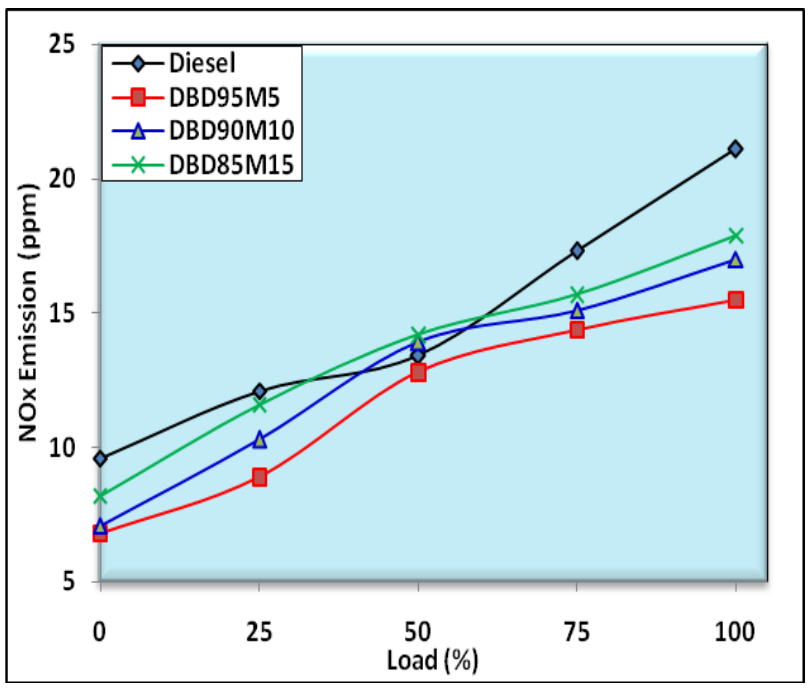

Fig. 13:- $\mathrm{NO}_{\mathrm{x}}$ emission variation with load

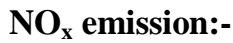

Temperature and oxygen availability are causing the formation of $\mathrm{NO}_{\mathrm{x}}$. Oxygen is always available in the combustion chamber and the only factor to be considered is the temperature of the combustion chamber. Temperature is depending on calorific value of fuel used; mean effective pressure during combustion and also on heat of fuel vaporization. From figure 13 the $\mathrm{NO}_{\mathrm{x}}$ emission is higher at increased loads; this is due to the high temperature produced during combustion using large fuel quantity. With methanol and biodiesel usage the combustion temperature is low due to low calorific value and the high latent heat of vaporization of methanol. This lowers the flame temperature due to less heat energy after combustion decreases in $\mathrm{NO}_{\mathrm{x}}$ emissions. Compared to diesel, the emission of $\mathrm{NO}_{\mathrm{x}}$ for M5, M10 and M15 are less by 23.4\%, 19.4\% and 15.3\% respectively.

\section{Conclusions:-}

The conclusions drawn from the present work are as follows:

1. Methanol 15\% in the mixture had improved efficiency than M5 and M10 but less than diesel fuel. Low exhaust gas temperature with methanol blends operation and high consumption of fuel due to low calorific value.

2. The $\mathrm{CO}$ emission for mixture fuels with methanol is far less than neat diesel. Increase in methanol percentage and load on the engine, decreases HC emissions for testing blend fuels and M15 blend fuel have $25.6 \%$ less than diesel at full load.

3. High oxygen content of methanol in blended fuel increase the heat of evaporation, which is an advantageous for reducing both $\mathrm{NO}_{\mathrm{x}}$ and soot compared to diesel fuel.

\section{References:-}

1. T Nibin, A P Sathiyagnanam, S Sivaprakasam and C G Saravanan, "Investigation on Emission Characteristics of a Diesel Engine Using Oxygenated Fuel Additive", Journal of Institution of Engineers (India), 2005; 86, 5154.

2. R J Zhu, X B Wang, H Y Miao, X F Yang and Z H Huang, "Effect of Dimethoxy Methane and Exhaust Gas Recirculation on Combustion and Emission Characteristics of a Direct Injection Diesel Engine", Fuel, 2011; 90(5), 1731-1737.

3. Y Ren, Z H Huang, D M Jiang, L X Liu, K Zeng, B Liu and X B Wang, "Engine Performance and Emission Characteristics of a Compression Ignition Engine Fuelled with Diesel/Dimethoxy Methane Blends", Proceedings of IMechE, Part D: Journal of Automobile Engineering, 2005; 219, 905-914.

4. S C Sorenson and S E Mikkelsen, "Performance and Emissions of a 0.2731 Direct Injection Diesel Engine Fuelled with Neat Dimethyl Ether", SAE Transactions, 1995; 104, 80-90.

5. Gong Yanfeng, Liu Shenghua, Guo Hejun, Hu Tiegang, Zhou Longbao, "A new diesel oxygenate additive and its effects on engine combustion and emissions", Applied thermal Engineering, 2007; 27(1), 202-207.

6. M Husnawan, H H Masjuki, T M I Mahlia, S Mekhi-lef and M G Saifullah, "Use of Post Flame Metal based and Oxygenated Additive Combination for Biodiesel-Diesel Blends", Journal of Scientific and Industrial Research, 2009; 68, 1049-1052. 
7. J C Ball, M A Gonzalez, C Lapin and E Linley, "Di-methoxy Methane in Diesel Fuel", SAE Paper No. 200101-3627.

8. M Iranmanesh, J P Subrahmanyam and M K J Babu, "Potential of Diethyl Ether as a Blended Supplementary Oxygenated Fuel with Biodiesel to Improve Combustion and Emission Characteristics of Diesel Engines", $S A E$ Paper No. 2008-01-1805, 2008.

9. Venkateswara Rao P and B V Appa Rao, "Performance and emission characteristics of DI diesel engine with COME-Triacetin additive blends as fuel", International Journal of Energy and Environment, 2012; 3(4), 629638.

10. Venkateswara Rao P., S. Ramesh, "Optimization of Biodiesel production parameters (Pongamia pinnata oil) by transesterification process", Journal of Advanced \& Applied Sciences, 2015, 3(3): 84-88.

11. N. Miyamoto, H. Ogawa and T. Arima, "Improvement of Diesel Combustion and Emissions with Addition of Various Oxygenated Agents to Diesel Fuels," SAE Paper No. 962115, 1996.

12. Bhale P V, Deshpande N V and Thombre S B, "Improving the Low Temperature Properties of Biodiesel Fuel", Renewable Energy, 2009; 34, 794-800. 